\title{
Failure of Montmorillonite K10 or Silica Gel to Promote the Conversion of Phenols to Quinones by Several Oxidants
}

\author{
E. J. Behrman* \\ Department of Biochemistry, The Ohio State University, Columbus, OH 43210, US
}

There have been a number of recent reports of the oxidation of phenols to quinones in good to excellent yields under exceptionally mild conditions when promoted by Montmorillonite $\mathrm{K} 10^{1-3}$ or silica gel. ${ }^{4}$ The oxidants are perborate, ${ }^{1}$ iodic acid, ${ }^{2}$ so-called percarbonate, ${ }^{3}$ and peroxydisulfate. ${ }^{4}$ I have been unable to reproduce these results. Table 1 summarizes the published yields for the oxidations of phenol and hydroquinone together with my findings. Reactions were carried out according the references except that analyses were done by extraction into chloroform and measurement of the absorbance at $440 \mathrm{~nm}$ where $p$-benzoquinone has $\varepsilon=22.3 \mathrm{~mol}^{-1} \mathrm{~L} \mathrm{~cm}^{-1}$. The temperature was not specified for the oxidations by percarbonate and perborate; I used $25^{\circ} \mathrm{C}$.

Table 1. Oxidations of phenols to $p$-benzoquinone on Montmorillonite K10 or silica gel

\begin{tabular}{lcc}
\hline & \multicolumn{2}{c}{$\begin{array}{c}\text { \% Yield } \\
\text { Reported }\end{array}$} \\
\cline { 2 - 3 } Oxidant & Phound) from \\
\hline Peroxydisulfate $^{4,5}$ & $55(1)$ & Hydroquinone \\
Percarbonate $^{3}$ & $55(1)$ & $92(13)$ \\
Perborate $^{1}$ & $56(4)$ & $91(24)$ \\
Iodic acid $^{2}$ (heating) & $96(6)$ & $93(7)$ \\
\hline
\end{tabular}

There is a recurring statement in the experimental sections of references 1 to 4 . This is that the quinones were said to be freed of contaminating phenols by washing a chloroform solution of the crude reaction mixture with $5 \% \mathrm{NaOH}$. This cannot be correct as quinones undergo a very rapid reaction with hydroxide ions; the half-time with $1 \mathrm{~mol} \mathrm{~L}^{-1} \mathrm{OH}^{-}$at $22{ }^{\circ} \mathrm{C}$ is about $0.3 \mathrm{~s}^{6}{ }^{6}$ Accordingly, I have found that that when 1,4-benzoquinone is dissolved in chloroform and then shaken with $5 \% \mathrm{NaOH}$, the yellow color of the quinone vanishes immediately from the chloroform layer and appears in the aqueous phase with a darkening reddish color. Rapid addition of $\mathrm{HCl}$ does not reverse this process.

I have also found that the apparent yield of quinone can be slightly increased (to $\mathrm{ca}$. 5\%) by conducting the initial extraction with methanol instead of chloroform. This is probably because any quinhydrone that is formed is rather insoluble in chloroform.

The iodic acid oxidations reported in reference 2 produce highly colored complex mixtures of a number of oxidation products. The NMR spectrum shows that the $p$-benzoquinone singlet at $\delta 6.79$ is approximately $6 \%$ of the protons in the aromatic region.

\section{References}

1. Hashemi, M. M.; Eftekhari-Sis, B.; Khalili, B.; Karimi-Jaberi, Z.; J. Braz. Chem. Soc. 2005, 16, 1082.

2. Hashemi, M. M; Akhbari, M.; Russ. J. Org. Chem. 2005, 41, 935.

3. Hashemi, M. M.; Khalili, B.; Eftekhari-Sis, B.; Org. Chem. (Rajkot, India) 2006, 2, 110.

4. Hashemi, M. M.; Karimi-Jaberi, Z.; Eftekhari-Sis, B.; J. Chem. Res. 2005, 160.

5. Behrman, E. J.; J. Chem. Res. 2006, 412

6. Eigen, M.; Matthies, P.; Chem. Ber. 1961, 94, 3309.

Received: November 16, 2007

Published on the web: December 13, 2007 